EISSN: 2706 -7947 ISSN: 2077- 4613

DOI: 10.36632/mejas/2021.11.2.31

Journal homepage: www.curresweb.com

Pages: 384-399

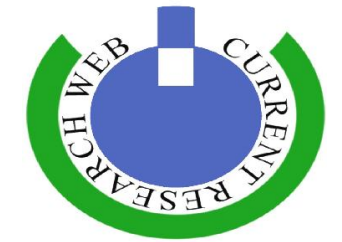

\title{
Structural Features and Incremental Stress History of the Granites of Wadi Dara Area, North Eastern Desert, Egypt
}

\section{Hassan El Sundoly}

${ }^{1}$ Nuclear Materials Authority (NMA) Cairo Egypt.

Received: 11 January $2021 \quad$ Accepted: 10 April Published: 15 April 2021

\begin{abstract}
Wadi Dara area, located at the North Eastern Desert of Egypt, is covered by metavolcanics, diorites, granodiorites, Dokhan volcanic, Hammamat sediments and younger granites. Brittle tectonic analysis on the younger granites of Gabal (G.) Dara and G. Umm Swassi have been carried out on 637 field measurements in 22 sites, using Win-Tensor computer program. Analysis of fault slip data revealed that 232 faults (36.4\%) are of extensional (normal), and 405 faults $(63.6 \%)$ belong to compressional and allowed computation of 78 paleostress tensors. These tensors are distinguished as 27 tensors corresponding to extensional faulting and 51 tensors corresponding to compressional faulting. The structural elements of younger granites of Gabal Dara and Gabal Umm Swassi were statistically treated and stress analyses were carried out on these structural data to delineate the paleostresses, affected the granites. These granites are subjected to four compressional and four extensional phases. The four compressional phases can be grouped into four main events as the following: E-W to WNW-ESE, NESW to ENE-WSW, NW-SE to NNW-SSE and N-S to NNE-SSW compressional events. While the four extensional phases can be grouped into also four main events as the following: N-S to NNE-SSW, NWSE to NNW-SSE, NE-SW to ENE-WSW and E-W to WNW-ESE extensional event. Significant radioactive anomalies are detected in pegmatites of the younger granites, which occur along NE-SW trend. Radiometric survey for most of these pegmatites gives abnormal measurements reach up to 6000 cps with $U$ content ranging from $600 \mathrm{ppm}$ to $900 \mathrm{ppm}$. In these pegmatites, radioactive minerals, recognized under Scanning Electron Microscope, are ishikawaite (U-rich variety of samarskite group) thorite, uranothorite, zircon and allanite. The structural studies at these anomalies of pegmatites indicated that the NW-SE extensional event is the main role for the crystallization of uranium mineralization in the study area.
\end{abstract}

Keywords: stress analysis; structure; radioactivity; uranothorite; Dara.

\section{Introduction}

A general agreement that the intrusion of granitic magmas during orogenic events is believed to be due to extensional movements resulted during post orogenic collapse (Searle et al., 1997; Sylvester, 1998). The upward of the resulted melts is due to compression (Collins and Sawyer, 1996; Brown and Solar, 1998). Shear zones and faults resulted from the orogenies provide pathways for magma extraction and ascent in the crust (Hutton, 1988; Grocott et al., 1994; Sawyer, 1994; Brown and Solar, 1998). Therefore, granitic plutons are mainly related to regional structure events as result of compression rather than extension (Solar et al., 1998).

Hamimi et al. (2019) stated that NW-SE faults and shear zones are the most dominated structural features in the Eastern Desert playing an important role in the structural features of the Neoproterozoic Pan-African belt. They also noted that the NED is dominated by fault/joint systems and characterized by younger granites intrusions. The NE-SW structural trend is predominant set which affecting on NED Stern (1985). Gabal Dara and Gabal Umm Swassi represent a part of the Egyptian Neoproterozoic Pan-African belt. They lie at the northern part of the Nubian Shield in the north Eastern Desert. They are located between latitudes $27^{\circ} 54^{\prime}-28^{\circ} 02^{\prime} \mathrm{N}$ and longitudes $32^{\circ} 54^{\prime}-33^{\circ} 2^{\prime} \mathrm{E}$ (Fig. 1). 
The aim of this work is to study the tectonic and structure evolution which affected the younger granite of Wadi Dara and the attempt to be connected with the results of radiometric survey
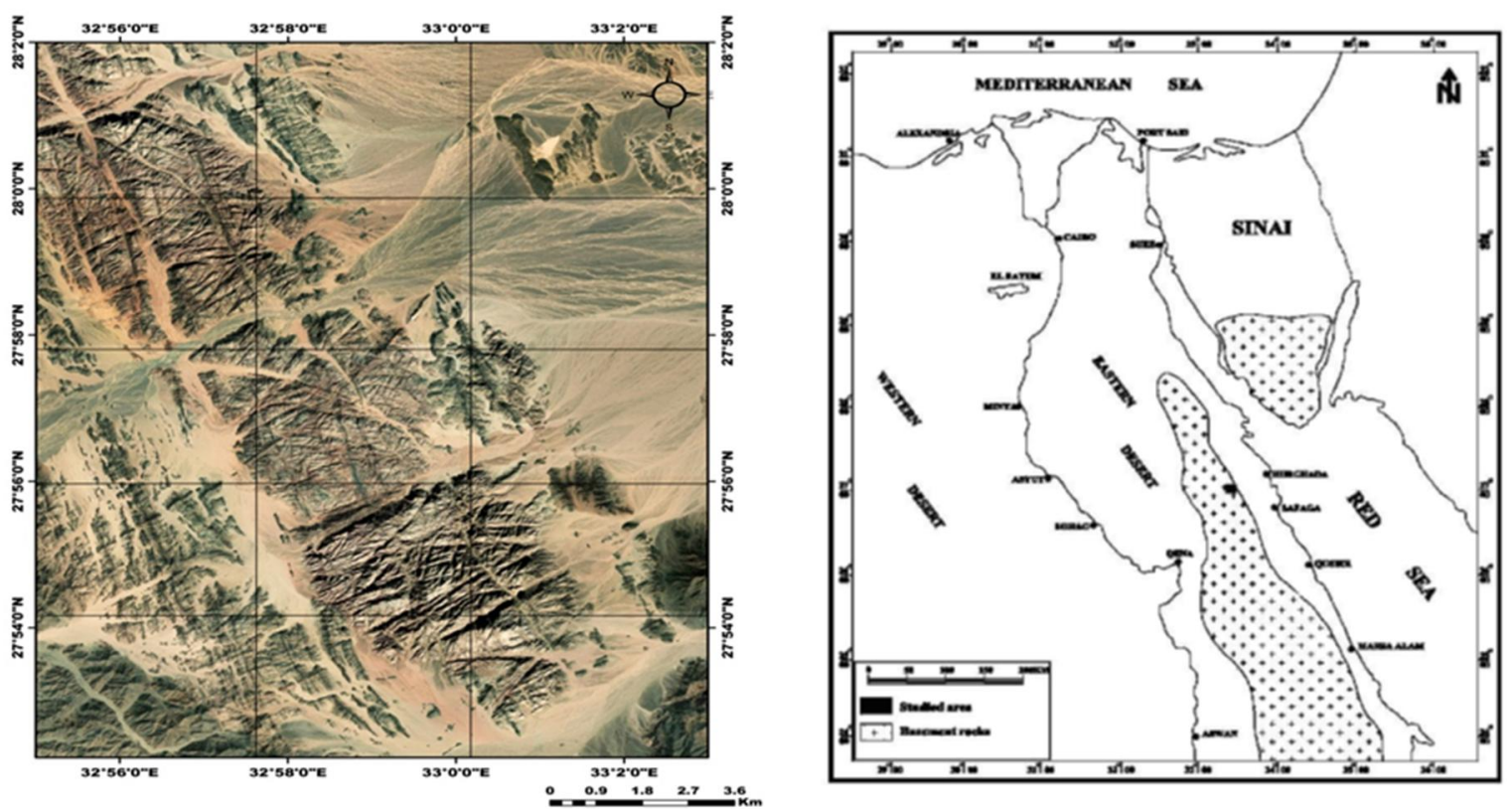

Fig. 1: Satellite (left) and location map (right) of Wadi Dara area, north Eastern Desert, Egypt.

\section{2: Geological Setting}

The detailed geological map shows that the Wadi Dara area is characterized by presence of different rocks of igneous and metamorphic that represented from the older to the younger as shown in the geological map (Fig. 2).

\section{Post-granite dykes \\ Younger granites \\ (Younger) \\ Hammamat sediments \\ Dokhan Volcanics \\ Granodiorites \\ Diorites \\ Metavolcanics \\ (Older)}

The metavolcanics represent the oldest rock unit in the Wadi Dara area. They form moderate to high mountains and crop out at south western side of the map area (Fig.2). They consist of intermediate to basic volcanics tuffs and flows which have been subjected to regional metamorphism. The metavolcanics are intruded by diorites and granodiorites at southern side of the study area, west of Gabal Dara. Contact of the metavolcanics versus the Dokhan Volcanics is tectonic rather than intrusive.

Diorites occur as low to moderately hilly masses to the west of G. Dara (Fig.2). Their composition is somewhat complex where they range from diorites and quartz diorites. They are melanocratic greenish to grayish in colour, medium to coarse grained showing onion weathering, and subjected to deformation and gneissosity. They are overlain by metavolcanics, and are intruded by granodiorites with fault contacts.

The granodiorites occur as elongated to sub rounded low to moderate small separated hills with gentle slopes at the western side of Gabal Dara and Gabal Umm Swassi (Fig.2). They are whitish gray, leucocratic, medium to coarse grained, massive rocks which are highly sheared and foliated along the sheared zones and fault planes. These rocks are overlain by metavolcanics and Dokhan Volcanics (Fig.2), while they are themselves intruded by alkali feldspar granite. They are characterized by extensive exfoliation caused by mechanical weathering displaying blocky appearance and sometimes enclose abundant xenoliths of diorites and metavolcanics. They are dissected by a group of acidic, intermediate, mafic and alkaline dykes propagating in different trends and having different thickness.

The Dokhan Volcanic are an important stratigraphic unit within the Egyptian basement rocks. Their succession represents the younger unmetamorphosed volcanics in Wadi Dara area. They commonly form high conical hill landforms with rough topography. They occupy the southwestern and 
southeastern parts of the study area at Gabal El Nasb and Gabal El-Urf (Fig.2). The Dokhan volcanics are mainly composed of lava flows of intermediate to acidic composition and occur mainly as tuffs rather than flows. A few sheets or small lenticular masses of very fine-grained violet ignimbrite are also encountered. They have sharp contacts with both the diorites and granodiorites. The volcanics are highly silicified and sometimes brecciated, especially along and directly near the contacts.

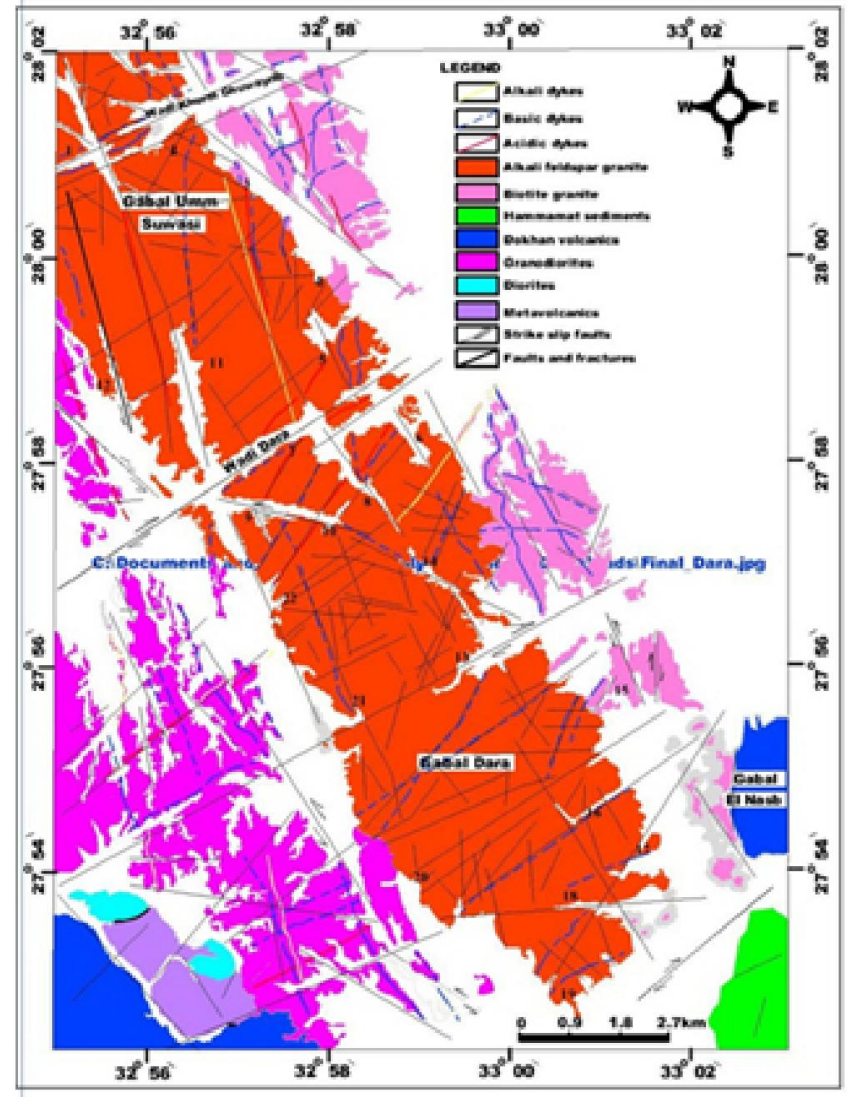

Fig. 2: Geological map of Wadi Dara area, north Eastern Desert, Egypt.

Numerous acidic and basic dykes, mainly striking E-W, NW-SE and NE-SW directions, are traversing these volcanics. The successive eruption of these volcanics yielded layered structure similar to that of sedimentary rocks. The Hammamat sediments constitute a thick succession, which exhibits clear bedding planes striking NNW-SSE with an average dip of $25^{\circ}$ to the SW. They also crop out at southern part of the study area (Fig.2). These rocks are brick, red, purple and grayish green to grey in colour and are characterized by coarsely bedded succession of sandstones (greywacke) and siltstones. The younger granites cover vast areas and represent the largest extent among all the studied rock types. Two main types of these granites can be distinguished: biotite granites and alkali feldspar granites. The biotite granites crop out in the eastern side of the mapped area at Wadi Khurm Ghuwayrib and Wadi Dara (Fig.2). They are commonly very coarse-grained, grade in colour from pinkish white to light pink colour with dark mica spots and are characterized by porphyritic texture. These granites intrude the Dokhan Volcanics and enclose enclaves and xenoliths of older rocks. While, these rocks are intruded by alkali feldspar granites with gradually contacts (Fig.2). The biotite granites are traversed by intermediate, felsic, mafic and alkaline dykes in different trend. The alkali feldspar granites form two high mountains with rough topography, namely Gabal Dara and Gabal Umm Swassi (Fig.2) in the eastern side of the study area. They form an elongated mass trending NNW-SSE, governed by the major tectonic parallel to the Gulf of Suez trend. The alkali feldspar granites are red; pink to pinkish medium to course -grained rocks showing highly jointed and highly weathered. They are dissected by numerous extensional and compressional faults in different direction. The alkali feldspar granites are cut by felsic, intermediate, mafic and alkaline dykes form dyke swarms having different trends. The periphery of Gabal Dara and Gabal Umm Swassi are characterized by the presence of pegmatite bodies mainly of the unzoned type. 
The contact of the alkali feldspar granites to the granodiorites is sharp intrusive contact; commonly carry them as roof pendants. The alkali feldspar granites yielded ages ranging from 591 to $602 \pm 11 \mathrm{Ma}$ (Daas, 2009).

Dykes are very common in the investigated area and there are felsic, intermediate, mafic and alkaline dykes that run in parallel and/or sub parallel sets. Generally, they have NNE-SSW, E-W, NWSE, ENE-WSW, NE-SW, NNW-SSE and N-S trends. Numerous dykes and dyke swarms are so small in their extension and thickness so that they are can't be traced, and thus are unmappable on the structural and geological map of the investigated area.

Felsic dykes are the oldest dykes in the investigated area, intruding the granite porphyry and less abundant felsites and rhyolites. They generally possess more than $1 \mathrm{~m}$ in thickness and may reach up to $\sim 5 \mathrm{~m}$, having steep walls and sharp contacts with the country rocks. These dykes are characterized by their creamy, rosy, reddish grey and brownish colours and cutting all the above mentioned rock units. They are occupying older fractures, mainly trending in the E-W, NNE-SSW and NE-SW directions.

Intermediate dykes are represented by andesite and their porphyries, which range in thickness from 1 to 5 meters and reaches up to 10 kilometers long in the NNW-SSE trend. These dykes are running in the NNW-SSE, NE-SW, NNE-SSW and ENE-WSW directions, usually in parallel to sub parallel sets. These dykes are hard, massive, and porphyritic and very fine grained with brownish green, greenish gray to dark gray colour. They mainly cut through all the older rocks groups of the investigated area.

Alkaline dykes are of trachytic composition. They have brick red, brown to rosy colour. They are traced for longest distances among other dykes especially at the central part of the investigated area, along Wadi Dara and Gabal Umm Swassi. Trachyte dykes cut the intermediate dykes (Fig.3) and are traversed by dolerite dykes at Wadi Dara. They range from 1 to 7 meters in width and trending in NNWSSE and ENE-WSW directions.

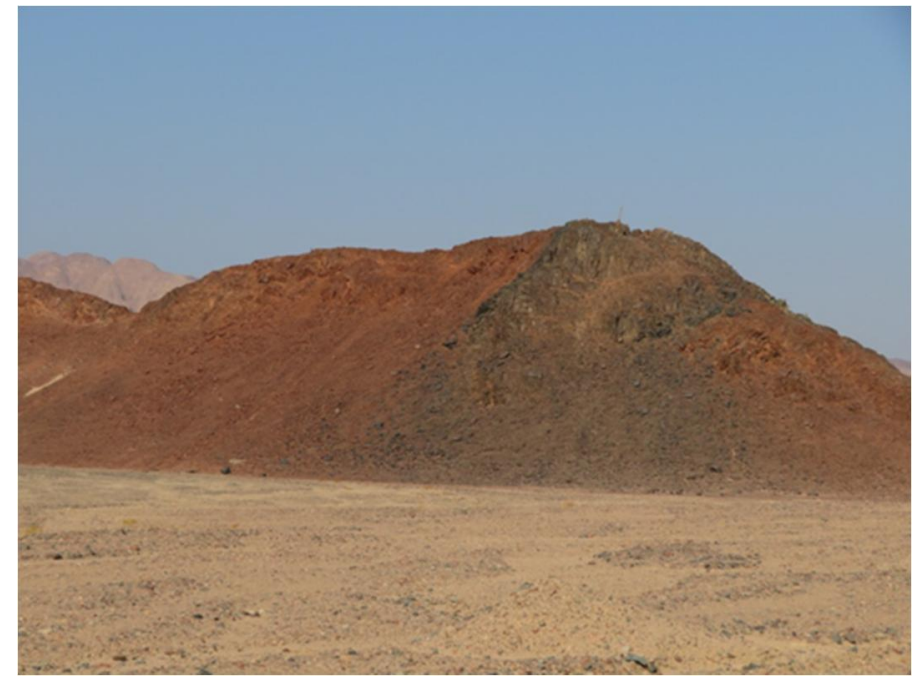

Fig. 3: Mafic Dyke striking $\mathrm{N} 50^{\circ} \mathrm{W}$ cutting trachyte dyke striking $\mathrm{N} 65^{\circ} \mathrm{E}$ in the entrance of Wadi Dara.

Mafic dykes are represented by dolerite and basalt. Dolerite dykes are medium-grained with dark gray colour; they cut the trachyte dykes and intermediate dykes (Fig.4\&5) and were traversed along fractures and joints in the granodiorites and alkali feldspar granites. Basalt is fine- grained with black colour; they cut the alkali feldspar granites. They are characterized by their long distances, up to 15 kilometer long and average thickness of about 6 meters. They have a NW-SE trending usually in parallel sets. 


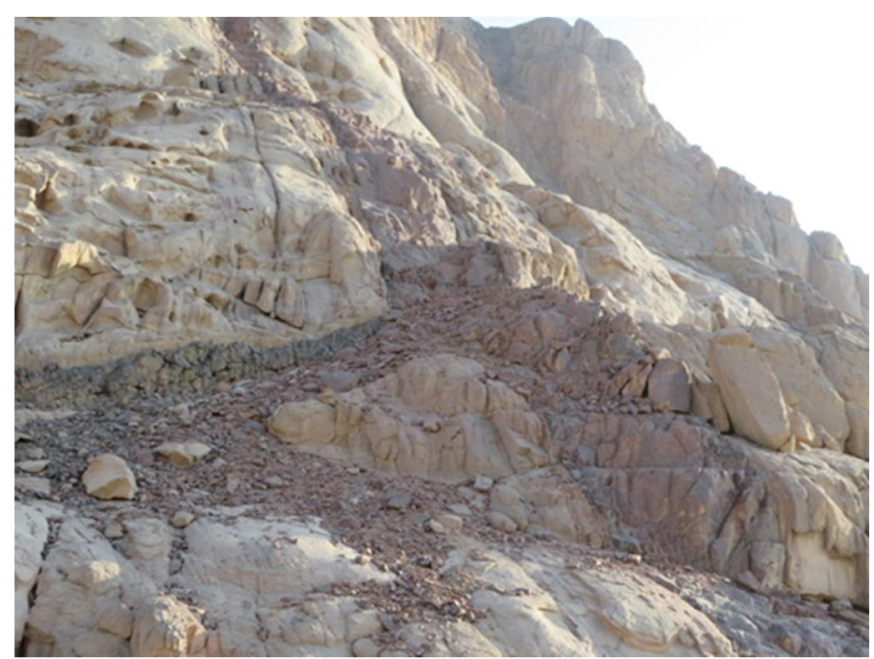

Fig. 4: Trachyte dyke striking $\mathrm{N} 30^{\circ} \mathrm{W}$ cutting intermediate dyke striking $\mathrm{N} 45^{\circ} \mathrm{E}$ in the granites of Wadi Dara.

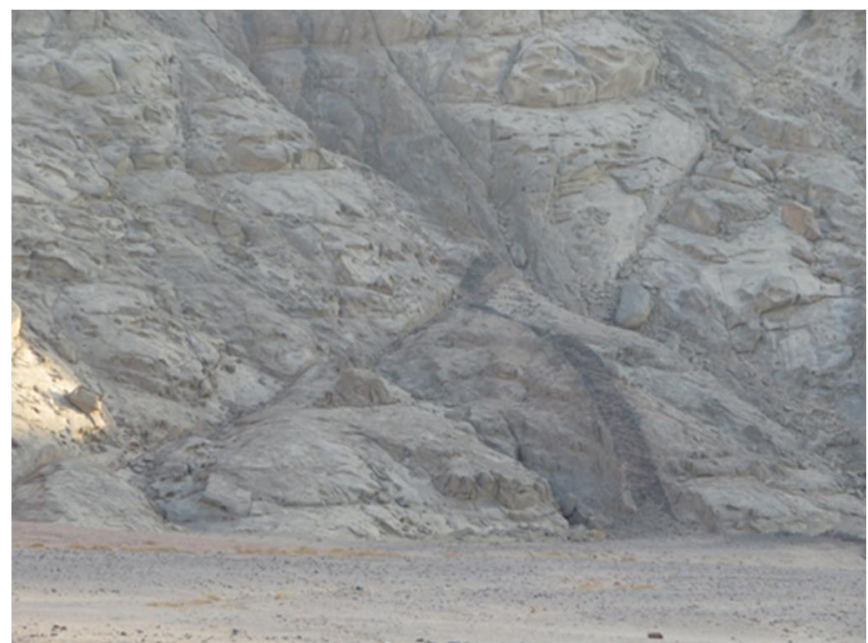

Fig. 5: Mafic Dyke striking $\mathrm{N} 40^{\circ} \mathrm{E}$ cutting intermediate dyke striking $\mathrm{N} 50^{\circ} \mathrm{W}$ in the granites of Wadi Dara.

\section{Methodology}

Method used for analyzing faults, started with observing fault plane surfaces with slickenlines and determined their fault types then measurements of numerous slickenlines on each fault plane with striation in the investigated area, was carried to reconstruct the paleostress axes by using the pressure/tension axes method (P/T method); computer program Win-Tensor, (Delvaux and Sperner., 2003); as well as, improved right dihedron method (computer program Win-Tensor; Delvaux and Sperner., 2003), that measurements the three principle stress axes, is used for analyzing tension and shear joints.

The gamma ray scintillometer; model RS-230 has been used to achieve field radiometric measurements. This instrument gives the field radioactivity of the rocks in terms of count per second (CPS) total, uranium concentration ( $\mathrm{ppm}$ ), thorium concentration ( $\mathrm{ppm}$ ) and potassium percent (K \%). At the Nuclear Materials Authority (NMA) X- ray diffraction Technique (XRD) model Philips PW3710/31 has been used to identify the radioactive minerals. The radioactive minerals analyze and investigate the structural features characteristics of the minerals, as well as to give a semi-quantitative evaluation of their elemental composition using the Environmental Scanning Electron Microscope ESEM-EDAX, at NMA Lab. 


\section{Results}

\subsection{Stress analysis of the granite of W. Dara}

The structural features of the north Eastern Desert of Egypt are modified by NE-SW tensional regime related to the NW-SE strike-slip Najd Fault System (Stern, 1985). Gabal Dara is a fault-bounded affected by a NW-SE- to NNW-SSE- stretching in the NW-SE and a contraction in the NE-SW. The study area is subjected to tectonic events displaying structural features, mainly represented by faults and joints. Faults are represented by strike slip type with some normal and reverse faults.

Statistical analysis of photo-lineation (faults and fractures) of Wadi Dara area has been subjected to poly-phase deformation due to a complex sequence of successive tectonic events. These phases are reflected on the Gabal Dara and Gabal Umm Swassi through a high density of faults and fractures in different trends depending on the causative stress tensors and the strength properties of the granite material (Fig. 6).

Lineaments analysis is carried out on fracture lineaments on the map (Fig. 7) traced from composite satellite images. Lineaments analysis was also used to establish the mutual relationships between different faults trends as possible, which is used later to establish the chronological sequence of the tectonic events that affected the area. The analysis is carried out on both the number and length of lineaments striking in different trends. But the arrangement according to the lengths is more reliable than that based on numbers.

The common fault trends based on their number proportions are ENE-WSW, NE-SW, NNWSSE and, E-W while based on their length proportions is NE-SW, ENE-WSW and NNW-SSE (Fig.8). Predominant trends of joints are NE-SW, ENE-WSW, E-W and N-S. The NE-SW and NNW-SSE are the master trends in the investigated area controlling the morphological and structural framework of the area followed by ENE-WSW trend, while the least common trends are NNE-SSW, N-S and WNWESE. Most of the major wadis are structurally controlled where they run along faults and shear zones. Generally, they are chiefly controlled by the intersection of the ENE-WSW (Qena-Safaga trend) and NW-SE faults and shear zones (Najd trend).

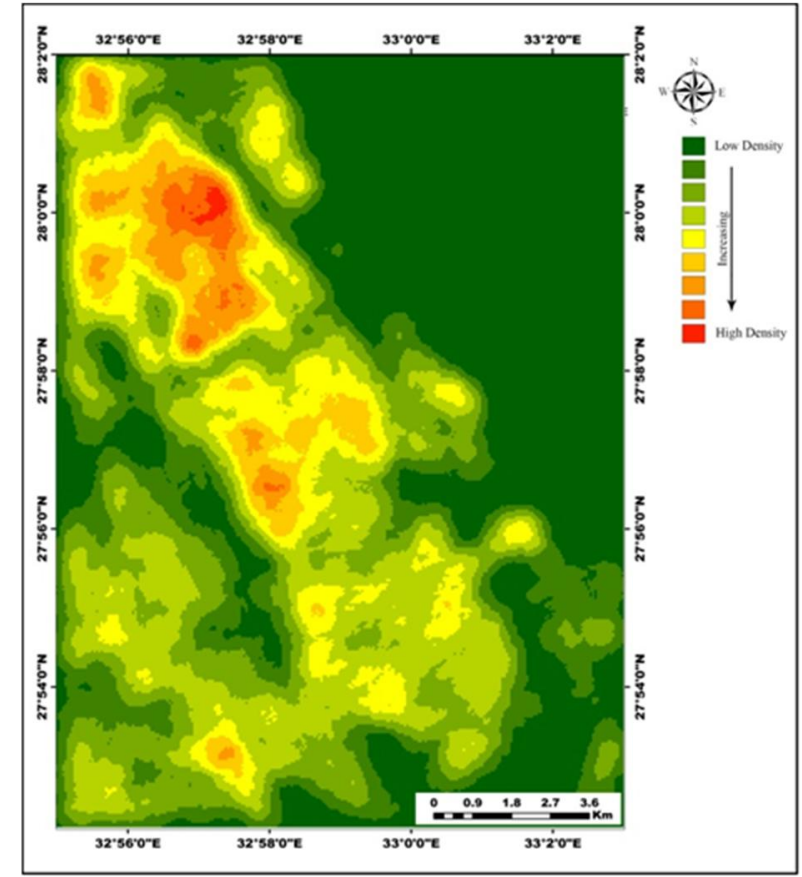

Fig. 6: Density map for the structure lineation of Wadi Dara area.

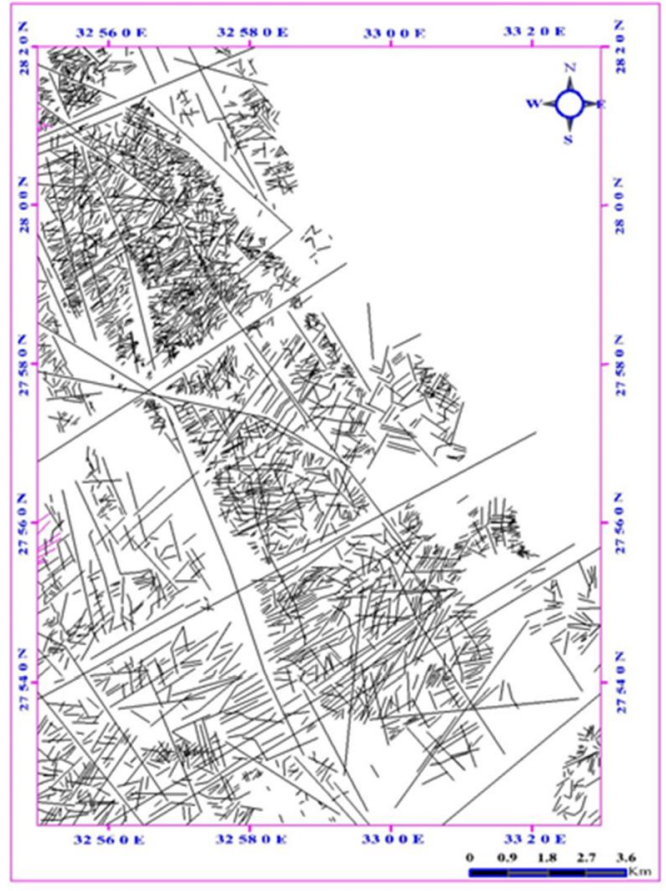

Fig. 7: Lineament structure map of Wadi Dara area. 


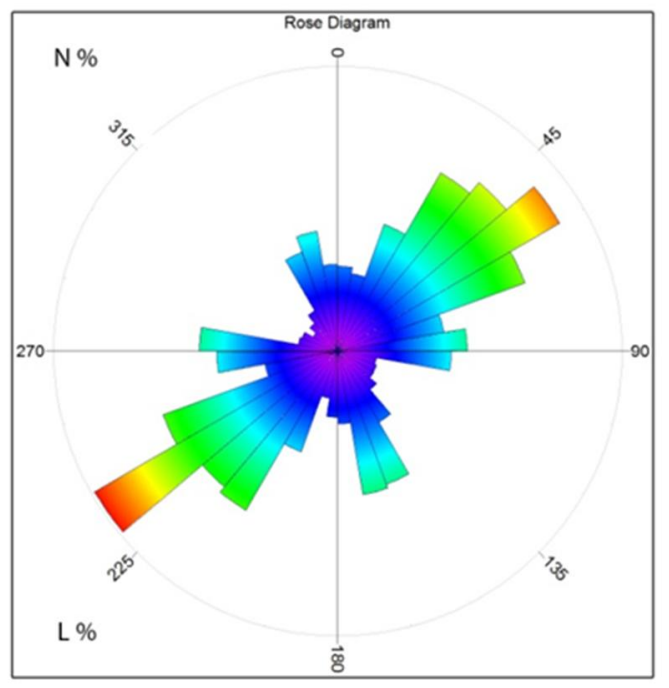

Fig. 8: Rose diagram showing the main trends of both number (N \%) and length (L \%) proportions of surface lineaments of Wadi Dara area.

Numerous faults of many attitudes and different movements are dissected the investigated area. Most of the recorded faults, in the study area, are characterized by their relative horizontal displacements (Fig. 9 a \& b) or the separation of different dykes (Fig.9c) and geological contacts, as well as the various associated brecciation, different alterations, slickensides (Figs.9 d \&e) and intense shearing along their fault zones, or the abrupt change in wadi lines.

Fault plane straie analysis was carried out at 22 locations within the younger granites. Most locations show polyphase slip systems and display some complicated fault patterns including oblique and inherited fault slips. The field measured 637 faults in younger granites are classified into 232 tension faults (normal faults) and 405 compression faults (strike slip and reverse faults). The analysis of the strike trend of 232 normal faults (Fig.10a) indicates that they can be classified in eight frequent classes arranged as following in decreasing order: 1- NW-SE trend 2- WNW-ESE trend 3- NNE-SSW trend 4NE-SW trend 5- N-S trend 6- ENE-WSW trend 7-NNW-SSE trend 8-E-W trend.

The analysis of the dip angles reveals that the most frequent are very steep to nearly vertical angles followed by the nearly vertical, vertical angles, while the least frequent represented by the moderate to steep angles.

The analysis of the rake angles of slickensides reveals that the steep to very steep are the most frequent angles followed by the very steep and very steep to nearly vertical angles, moderate to steep, while the vertical angles appeared the least frequent angles.

The analysis of the strike trend of 405 compression faults (Fig. 10b) indicates that they can be classified in eight frequent classes arranged as following in decreasing order: 1-NE-SW trend 2- ENEWSW trend 3- NNE-SSW trend 4- NNW-SSE trend 5- NW-SE trend 6- E-W trend 7- N-S trend 8WNW-ESE trend.

The analysis of the dip angles reveals that the most frequent are very steep to nearly vertical angles followed by the vertical, steep, steep to very steep angles, while the least frequent angles are moderate to steep angles.

The analysis of the rake angles of slickensides reveals that the most frequent angles are the horizontal angles followed by the horizontal to nearly horizontal, horizontal, while gentle to moderate angles appear the least frequent angles.

Analysis of field measurements of 638 fault slip data using win tensor computer program (Delvaux and Sperner, 2003) revealed that 232 faults (36.52\%) are extensional (normal) type, and 403 faults $(63.48 \%)$ belong to compressional strike slip type and allowed computation of 78 paleostress tensors. These tensors are distinguished as 27 tensors corresponding to extensional faulting and 51 tensors corresponding to compressional phases of strike-slip fault systems. 

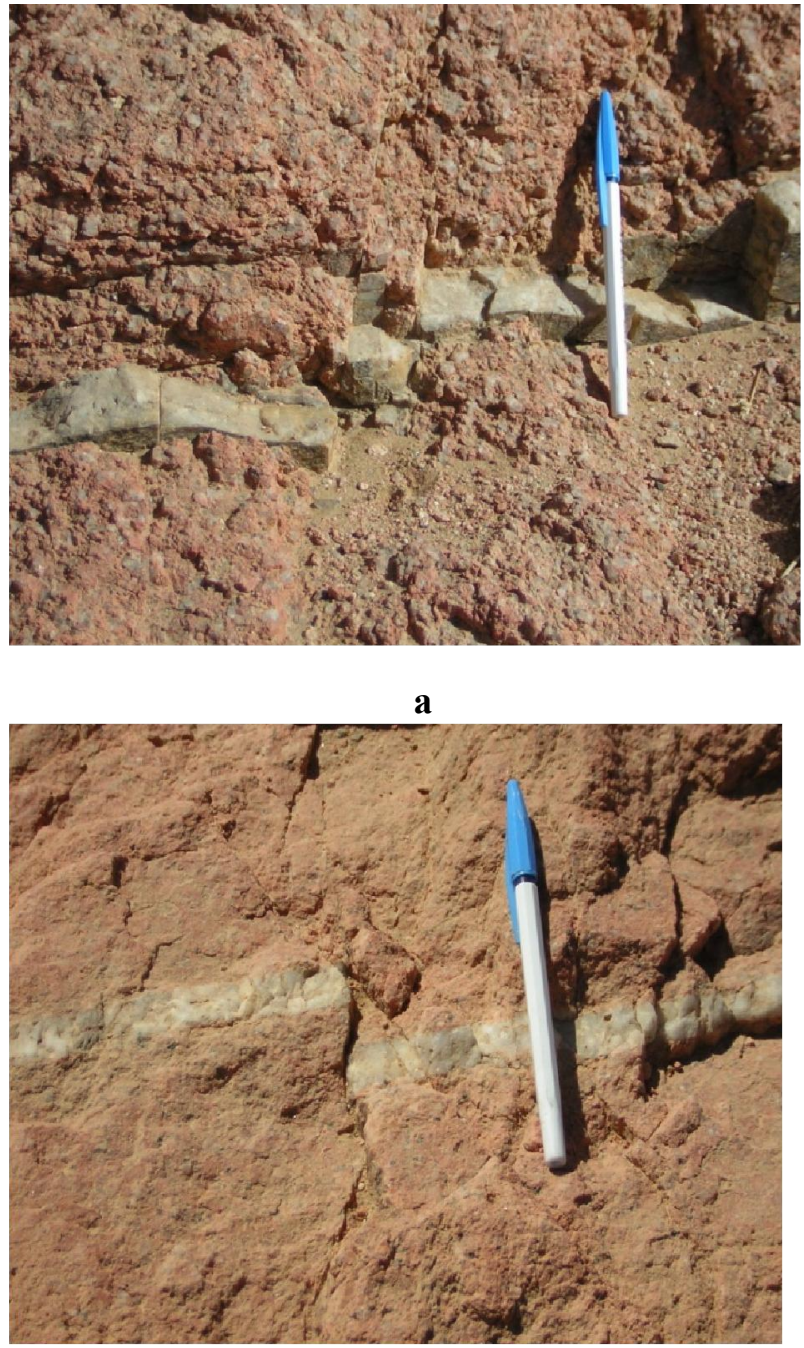

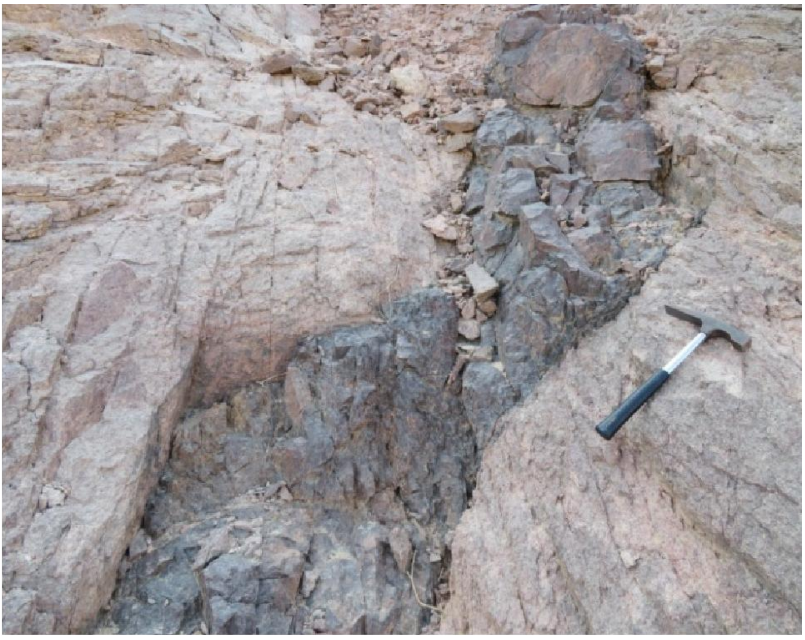

b

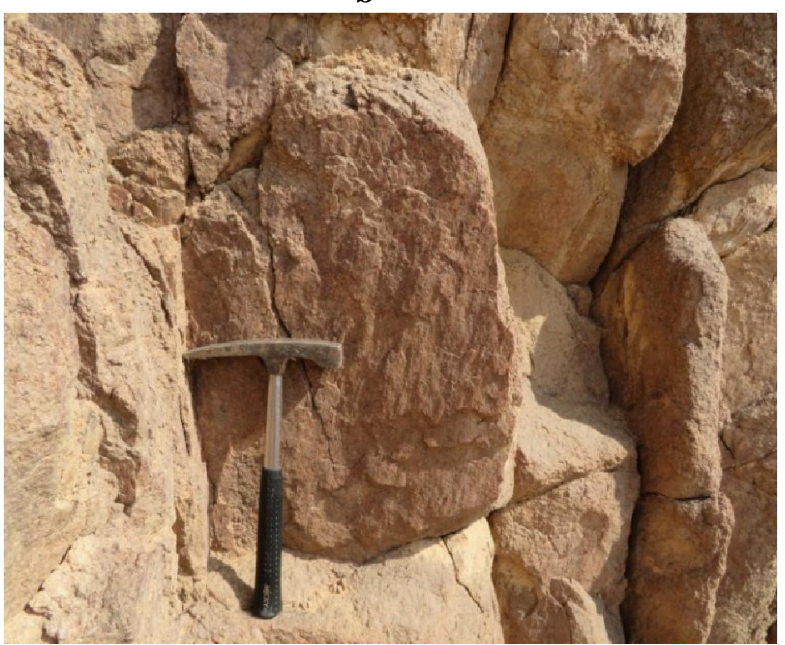

c

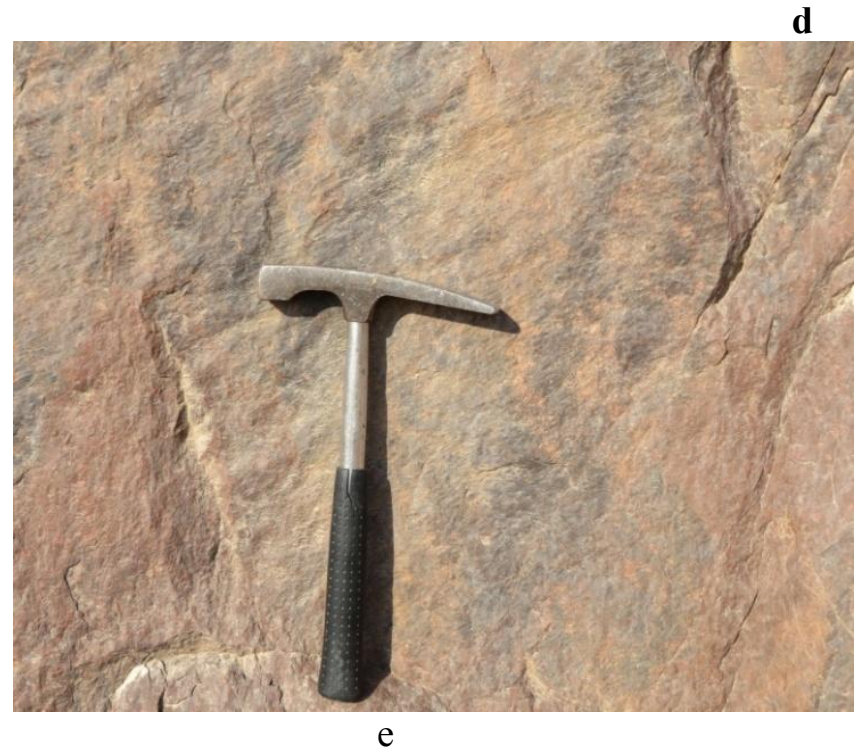

Fig. 9: a: NW-SE sinistral fault displacing silica vein striking NE-SW. b: Dextral fault striking N40E displacing a basic dyke striking N35W. c: Dextral fault striking N-S displacing silica vein striking E-W. d: Slickenside of normal fault e: Slickenside of strike slip fault 

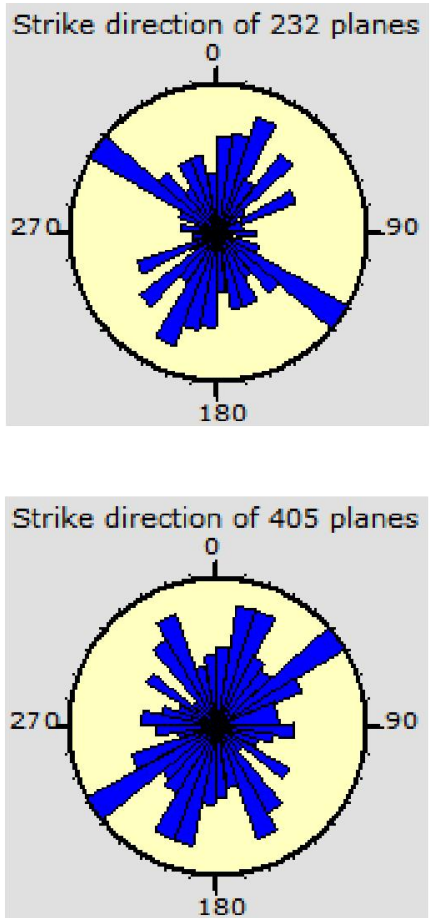

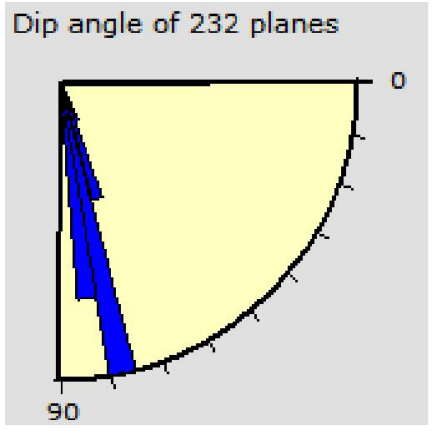

A

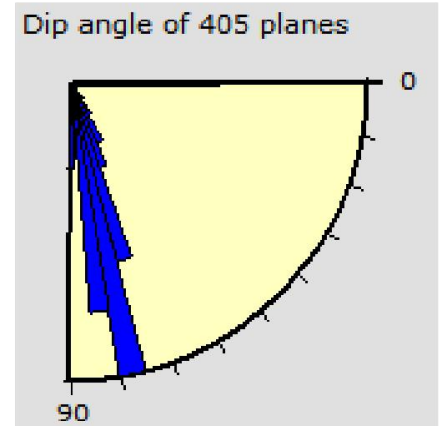

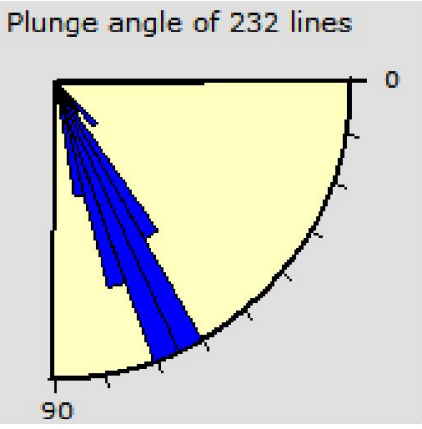

Plunge angle of 405 lines

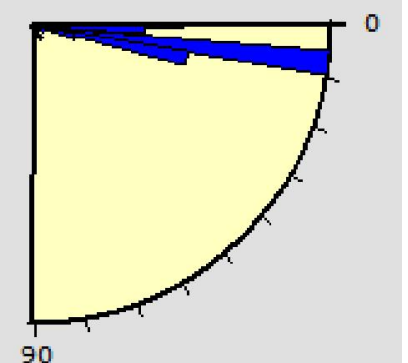

b

Fig.10: a: Geometry of 232 tensional faults (normal faults) measured in Wadi Dara area.

b: Geometry of 405 compressional faults (strike slip and reverse faults) measured in Wadi Dara area.

Four compressional phases are defined in the younger granites (Table1; Figs. 11-14). The calculated tensors of these phases are shown in the table and they can be grouped into four main events as the following: E-W to WNW-ESE, NE-SW to ENE-WSW, NW-SE to NNW-SSE and N-S to NNESSW compressional events. Compressional paleostress tensors are well determined in 22 sites. The strike-slip conjugate and reverse fault systems allowed the computation of 51 paleostress tensors in all stations.

The E-W to WNW-ESE major compressional event is computed from strike-slip faults measured in 9 sites (Fig. 11). The computed $\sigma 1$ for this event plunges between $8^{\circ}$ and $49^{\circ}$ in direction from $79^{\circ}$ to $110^{\circ}$ and between $10^{\circ}$ and $22^{\circ}$ in direction $275^{\circ}$ to $298^{\circ}$. This event is considered to be the oldest one in the younger granite, where some faults of this trend are injected with silica veins and are displaced by the N-S faults (Fig. 9c).

The NE-SW to ENE-WSW major compressional event is computed from strike slip and reverse faults measured in 18 sites (Fig.12). The computed $\sigma 1$ for this event plunges between $8^{\circ}$ and $22^{\circ}$ in direction from $35^{\circ}$ to $71^{\circ}$ and between $12^{\circ}$ and $46^{\circ}$ in direction $216^{\circ}$ to $255^{\circ}$. This event is considered to be younger than the E-W, WNW-ESE compression and N-S extension.

The NW-SE to NNW-SSE major compressional trend is computed from strike-slip and reverse faults measured in 12 sites (Fig.13). This compressional event is the most predominant event in the study area. The computed $\sigma 1$ for this event plunges between $10^{\circ}$ and $33^{\circ}$ in direction from $306^{\circ}$ to $342^{\circ}$ and between $8^{\circ}$ and $49^{\circ}$ in direction $124^{\circ}$ to $165^{\circ}$. Some of the NW-SE compression faults displacing some of the faults belonging to NW-SE extension (Fig.9a).

The N-S to NNE-SSW major compressional trend is computed from strike-slip faults measured in 12 sites (Fig. 14). The computed $\sigma 1$ for this event plunges between $11^{\circ}$ and $23^{\circ}$ in direction from $17^{\circ}$ to $350^{\circ}$ and between $7^{\circ}$ and $21^{\circ}$ in direction $171^{\circ}$ to $212^{\circ}$. Field observations indicate that some of the N-S compression faults displacing NW-SE and E-W silica veins (Fig.9c). Also, field and satellite image observations revealed that the conjugated faults system belonging to the N-S compression cut and displace the other trends of faults. So, the N-S to NNE-SSW compression is assigned to be the youngest compressional event in basement rocks in the area. ). This trend caused, the major folding in the Hammamat sediments which is a broad syncline whose axis trends E-W (Shalaby, 1985). 
Table 1: Summary of successive tectonic phases detected in younger granites of Wadi Dara.

\begin{tabular}{|c|c|c|c|c|c|}
\hline \multirow{2}{*}{ Tectonic phase } & \multirow{2}{*}{ Events } & \multicolumn{2}{|c|}{$(\sigma 1$ or $\sigma 3)$} & \multirow{2}{*}{$\begin{array}{c}\text { Reactivated Fault } \\
\text { trends }\end{array}$} & \multirow{2}{*}{$\begin{array}{l}\text { Reference } \\
\text { station }\end{array}$} \\
\hline & & Trend & Plunge & & \\
\hline E-W to WNW-ESE & EXT & $\begin{array}{c}84^{\circ}-113^{\circ} \text { and } \\
260^{\circ}-289^{\circ}\end{array}$ & $\begin{array}{c}1^{\circ}-18^{\circ} \text { and } \\
0^{\circ}-3^{\circ}\end{array}$ & NNE-SSW & $2-3-12-17-20$ \\
\hline N-S to NNE & $\mathrm{CP}$ & $\begin{array}{c}17^{\circ}-350^{\circ} \text { and } \\
171^{\circ}-212^{\circ}\end{array}$ & $\begin{array}{c}11^{\circ}-33^{\circ} \text { and } \\
7^{\circ}-21^{\circ}\end{array}$ & & $3-9-15-16-20$ \\
\hline $\begin{array}{c}\text { NE-SW to ENE- } \\
\text { WSW }\end{array}$ & EXT & $\begin{array}{c}40^{\circ}-64^{\circ} \text { and } \\
217^{\circ}-248^{\circ}\end{array}$ & $\begin{array}{c}0^{\circ}-3^{\circ} \text { and } 1^{\circ}- \\
2^{\circ}\end{array}$ & NW-SE-E-W & $6-7-9-10-13-16$ \\
\hline NW-SE to NNW-SSE & $\mathrm{CP}$ & $\begin{array}{c}306^{\circ}-342^{\circ} \text { and } \\
124^{\circ}-165^{\circ}\end{array}$ & $\begin{array}{c}10^{\circ}-33^{\circ} \text { and } \\
8^{\circ}-49^{\circ}\end{array}$ & & $7-9-11-12-17$ \\
\hline NW-SE to NNW-SSE & EXT & $\begin{array}{c}303^{\circ}-335^{\circ} \text { and } \\
132^{\circ}-151^{\circ}\end{array}$ & $\begin{array}{c}1^{\circ}-7^{\circ} \text { and } 1^{\circ}- \\
4^{\circ}\end{array}$ & $\begin{array}{c}\text { NE-SW-ENE- } \\
\text { WSW }\end{array}$ & $5-8-11-14-16$ \\
\hline $\begin{array}{c}\text { NE-SW to ENE- } \\
\text { WSW }\end{array}$ & $\mathrm{CP}$ & $\begin{array}{c}35^{\circ}-71^{\circ} \text { and } \\
216^{\circ}-255^{\circ}\end{array}$ & $\begin{array}{c}8^{\circ}-22^{\circ} \text { and } \\
12^{\circ}-46^{\circ}\end{array}$ & & $2-5-6-13-14-19$ \\
\hline N-S to NNE & EXT & $\begin{array}{c}29^{\circ}-352^{\circ} \text { and } \\
182^{\circ}-211^{\circ}\end{array}$ & $\begin{array}{l}1^{\circ}-4^{\circ} \text { and } 0^{\circ}- \\
1^{\circ}\end{array}$ & WNW-ESE & $1-3-4-19-21$ \\
\hline E-W to WNW-ESE & $\mathrm{CP}$ & $\begin{array}{c}79^{\circ}-110^{\circ} \text { and } \\
275^{\circ}-298^{\circ}\end{array}$ & $\begin{array}{c}8^{\circ}-49^{\circ} \text { and } \\
10^{\circ}-22^{\circ}\end{array}$ & & $1-4-8-18-22$ \\
\hline
\end{tabular}

$\mathrm{EXT}=$ Extension $\mathrm{CP}=$ Compression $\sigma 1$, for Compression $\sigma 3$, for Extension

Four extension phases are defined in the younger granites (Table1; Figs 15\&16). The calculated tensors of these phases are indicated in the table and they can be grouped in four main events as the following: N-S to NNE-SSW, NW-SE to NNW-SSE, NE-SW to ENE-WSW and E-W to WNW-ESE extensional events. Extensional paleostress tensors are well determined in 22 sites. The normal conjugate systems allowed the computation of 27 paleostress tensors in all stations.

The N-S to NNE-SSW major extensional trend is computed from normal faults measured in 5 sites (Fig. 15). This extensional event is the most predominant event in the study area. The computed $\sigma 3$ for this event plunges between $1^{\circ}$ and $4^{\circ}$ in direction from $29^{\circ}$ to $352^{\circ}$ and between $0^{\circ}$ and $1^{\circ}$ in direction $182^{\circ}$ to $211^{\circ}$. This event is assigned to be the second one in the younger granite. This event reactivated some faults related to the E-W and WNW-ESE compressions (Fig. 15, sites, 3 and 19).

The NW-SE to NNW-SSE major extensional trend is computed from normal faults measured in 6 sites (Fig. 15). The computed $\sigma 3$ for this event plunges between $1^{\circ}$ and $7^{\circ}$ in direction from $303^{\circ}$ to $335^{\circ}$ and between $1^{\circ}$ and $4^{\circ}$ in direction $132^{\circ}$ to $151^{\circ}$. This event rejuvenated some faults belonging to the NE-SW and ENE-WSW compressions (Fig.15, sites, 8 and 11). The NW-SE extensional event controls uranium mineralization in the study area.

The NE-SW to ENE-WSW major extensional trend is computed from normal faults measured in 7 sites (Fig. 16). The computed $\sigma 3$ for this event plunges between $0^{\circ}$ and $3^{\circ}$ in direction from $40^{\circ}$ to $64^{\circ}$ and between $1^{\circ}$ and $2^{\circ}$ in direction $217^{\circ}$ to $248^{\circ}$. This event reactivated some faults related to the NW-SE and NNW-SSE compressions (Fig. 16, sites, 6,9 and 113).

The E-W to WNW-ESE major extensional trend is computed from normal faults measured in 9 sites (Fig.16). The computed $\sigma 3$ for this event plunges between $1^{\circ}$ and $18^{\circ}$ in direction from $84^{\circ}$ to $113^{\circ}$ and between $0^{\circ}$ and $3^{\circ}$ in direction $260^{\circ}$ to $289^{\circ}$. This event reactivated some faults related to the N-S and NNW-SSE compressions (Fig. 16, sites 6, 14, 17 and 20). 


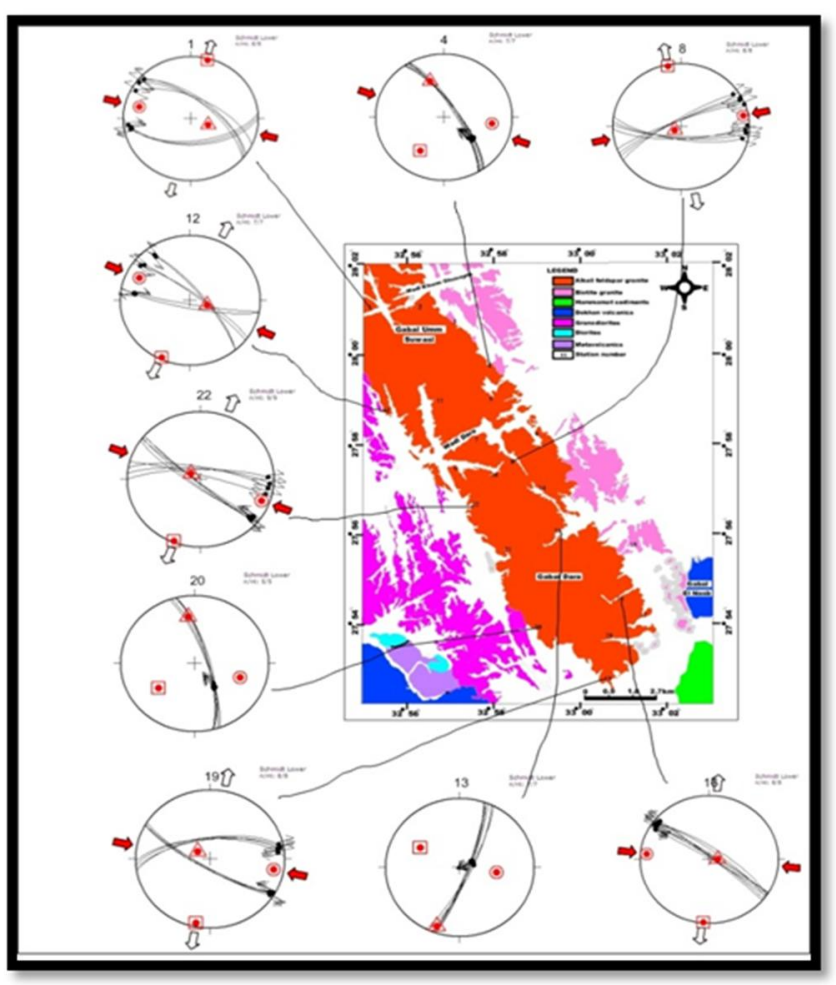

Fig. 11: Analysis of the data of the strike- slip faults and reverse faults corresponding to E-W to WNWESE compression paleostress tensors in younger granites, Gabal Dara area.

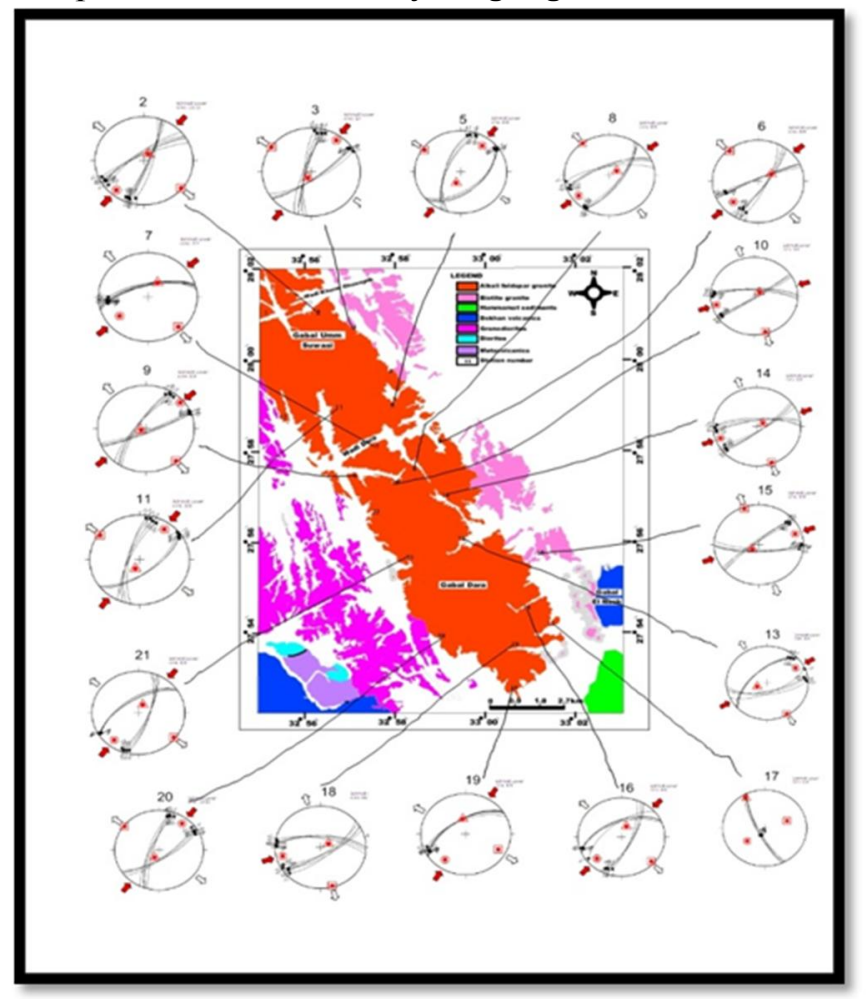

Fig. 12: Analysis of the data strike- slip faults and the reverse faults corresponding to NE-SW to ENEWSW compression paleostress tensors in younger granites, Gabal Dara area. 


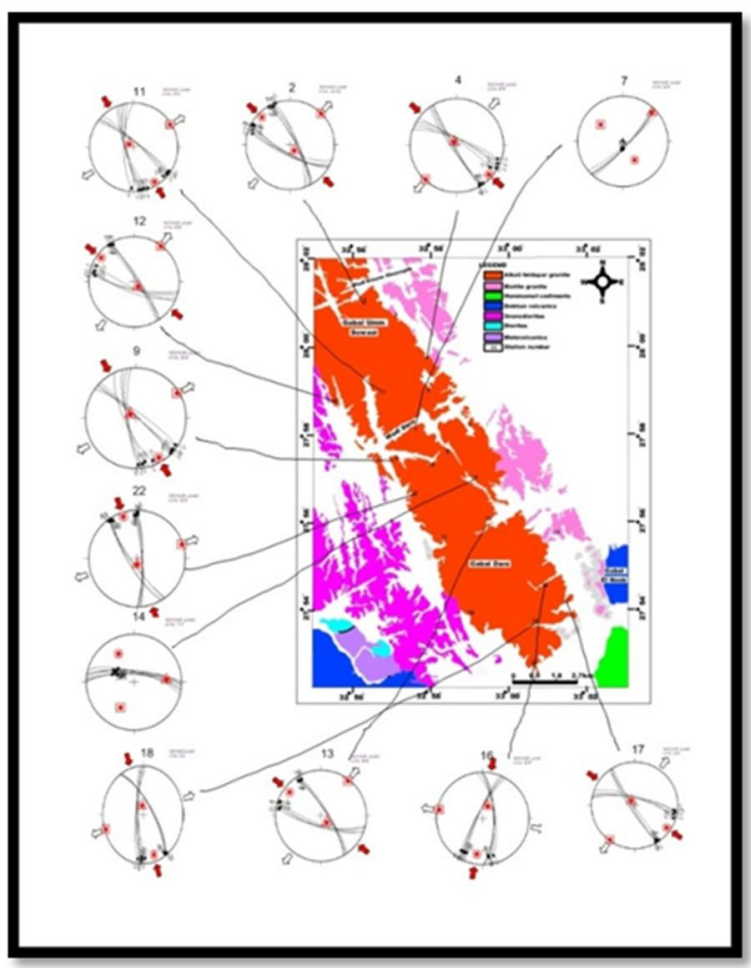

Fig. 13: Analysis of strike- slip and reverse fault planes data corresponding to NW-SE to NNW-SSE compression paleostress tensors in younger granites, Gabal Dara area.

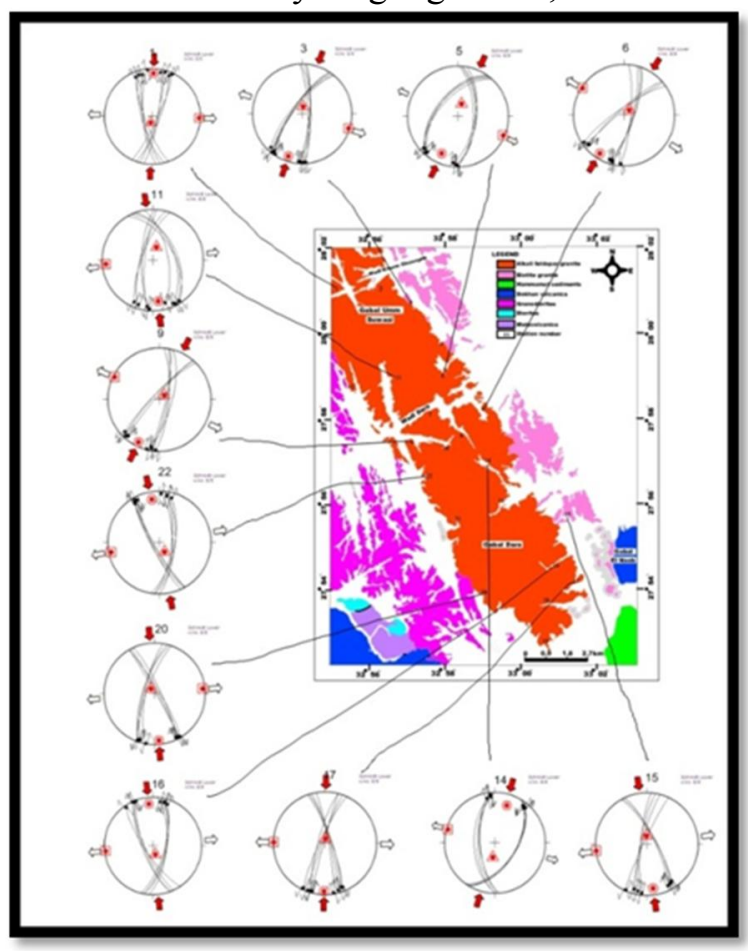

Fig. 14: Analysis of strike - slip fault planes data corresponding to N-S to NNE-SSW compression paleostress tensors in younger granites, Gabal Dara area. 


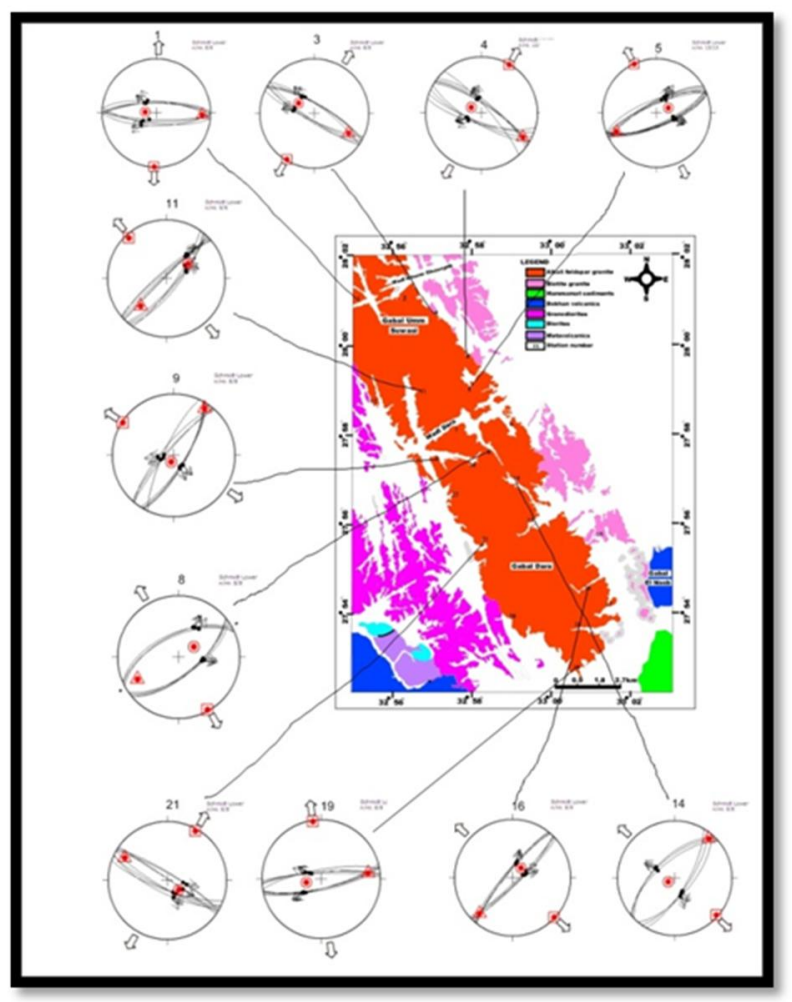

Fig. 15: Analysis of normal fault planes data corresponding to N-S to NNE-SSW and NW-SE to NNWSSE extension paleostress tensors in younger granites, Gabal Dara area.

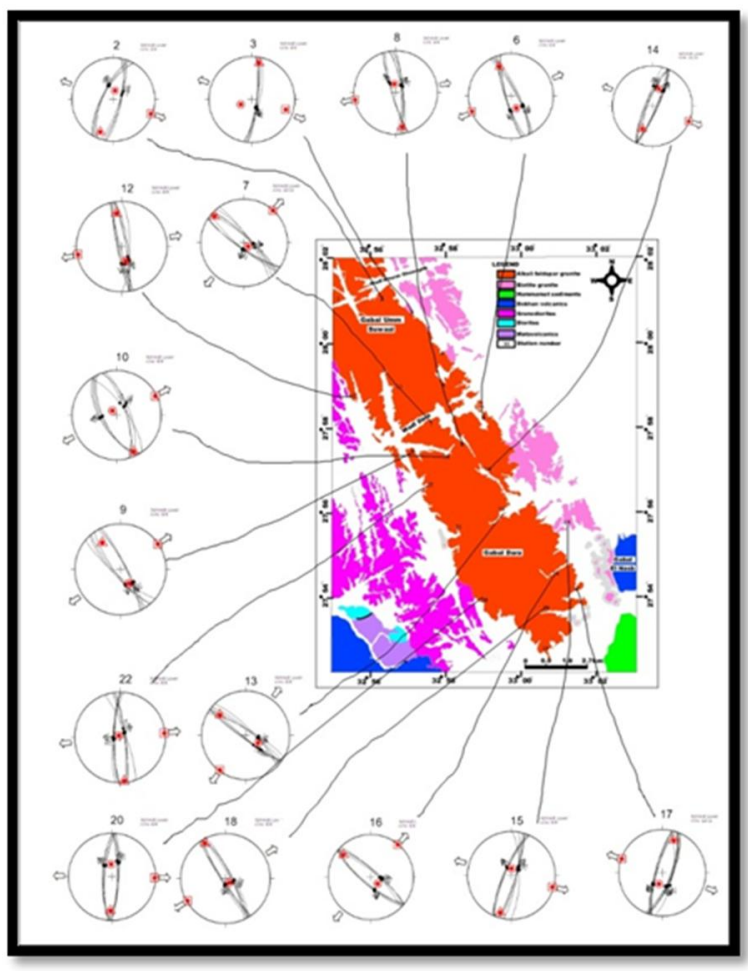

Fig. 16: Analysis of normal fault planes data corresponding to NE-SW to ENE-WSW and E-W to WNW-ESE extension paleostress tensors in younger granites, Gabal Dara area.

\subsection{Radiometric measurements}

In the study area significant of the radioactive anomalies were discovered by Shalaby (1985). Most of these anomalies present in pegmatites of the younger granites, which occur along NE-SW trend 
(Fig.17) with dip angles ranging from $60^{\circ}$ to $80^{\circ}$ to $\mathrm{SE}$ and NW. The uranium content of the younger granite ranges from $7 \mathrm{ppm}$ to $20 \mathrm{ppm}$. The radiometric survey for these pegmatites give measurements up to $6000 \mathrm{cps}$ with $\mathrm{U}$ content ranging from 600ppm to $900 \mathrm{ppm}$.

Mineralogical studies of the heavy mineral grains revealed extreme abundance of ishikawaite (U-rich variety of samarskite group) can be easily seen in hand specimen of the pegmatite bodies (Fig. 18a). It forms the major U-Nb-bearing mineral in the investigated area with common impurities of Ca, Ti, Si and REE. ESEM image and EDS spectrum of ishikawaite grains are illustrated in Figure (Fig. 18 b). Zircon is also recorded in high amounts mostly contains inclusions of uranothorite (Fig. 19a), and allanite-(Ce) (Fig. 19b).

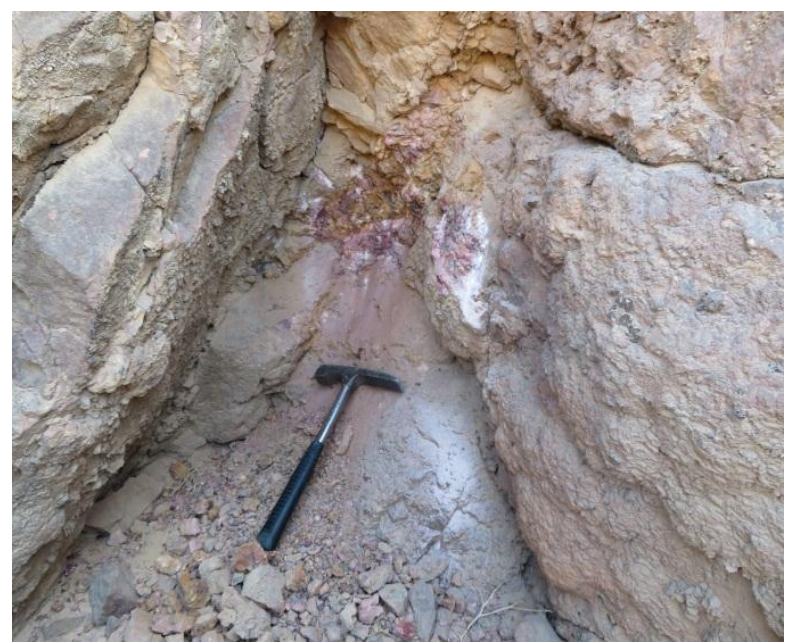

Fig. 17: Pegmatite intruded along a NE-oriented major fault.

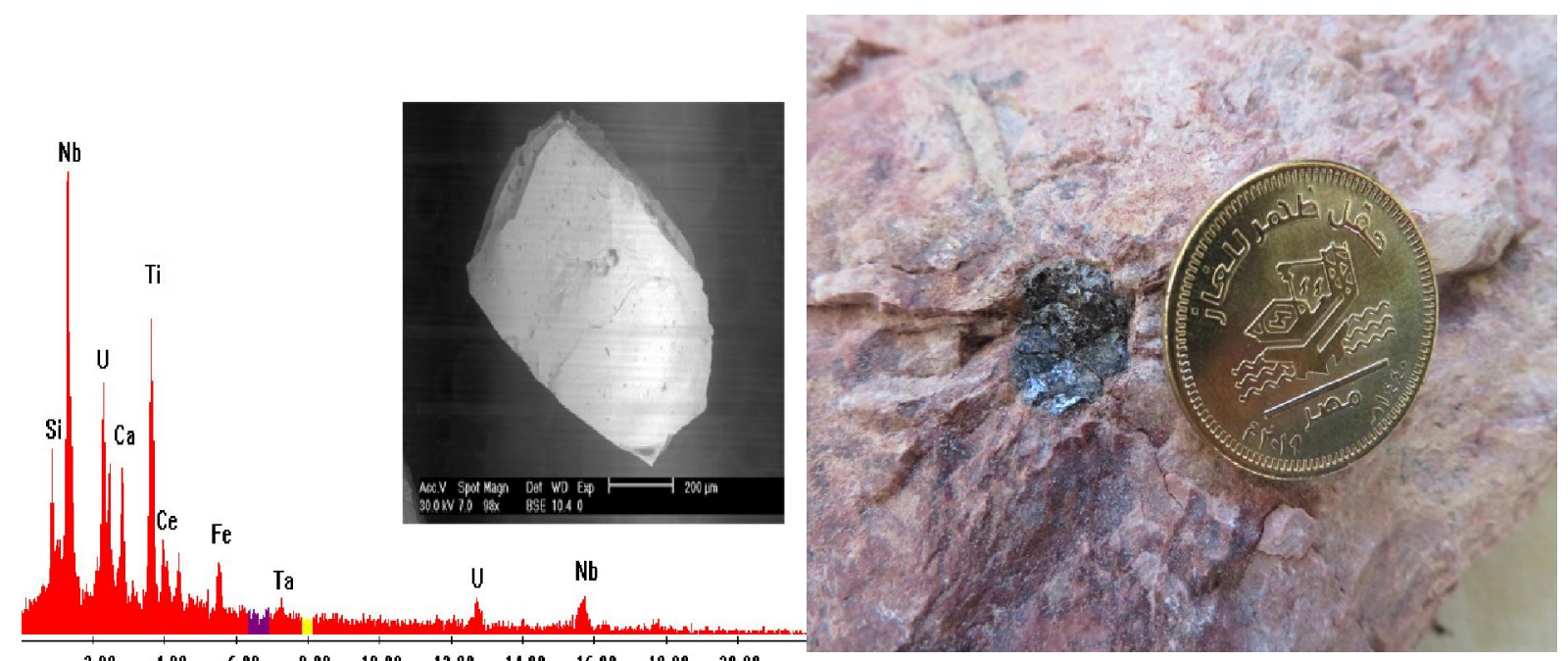

Fig. 18a. Back-scattered electron image and Fig. 18b. Crystal of ishikawaite mineral in EDAX chart of ishikawaite. hand specimen of the pegmatite bodies. 


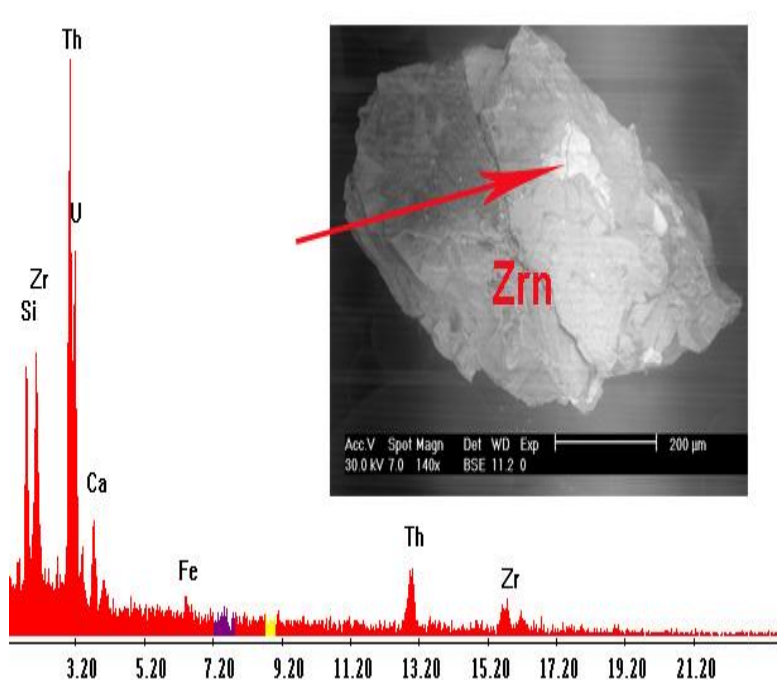

Fig. 19a: Back-scattered electron image and EDAX chart of uranothorite inclusions in zircon.

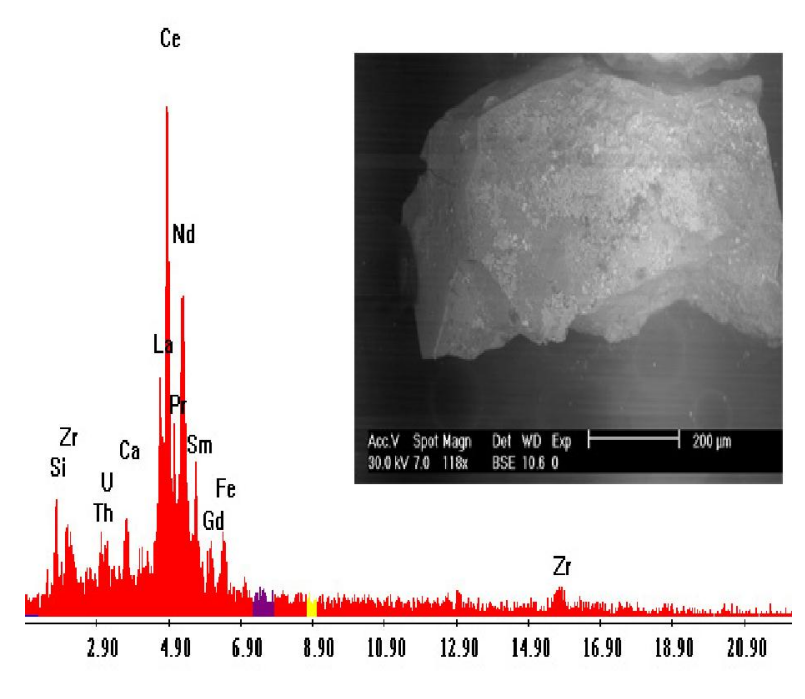

Fig. 19b: Back-scattered electron image and EDAX chart of allanite inclusions in zircon.

\section{Conclusions}

Gabal Dara pluton is an elongated alkali feldspar granitic mass intruded into voluminous PanAfrican country rocks along the NW to NNW shear zone in the Eastern Desert of Egypt known as NWSE strike-slip Najd fault system. The NW-SE sinistral Najd Fault trending initiated in Precambrian and rejuvenated at various times, probably during Paleozoic and late Jurassic times, and continuously, though of variable intensity, from late Cretaceous to the late Tertiary time (Perinçek et al.2006). The NW-SE sinistral Naid fault reactivation along the Paleozoic time produced a NE-SW extension major fault affecting the pegmatites of Gabal Dara. This major fault provided a pathway for the upwelling hydrothermal solutions, which were enriched in radioactive elements. Along its upwelling, the hematites and rare metals which enriched in these pegmatites capture the radioactive elements from the hydrothermal solutions and led to the crystallization of the radioactive minerals along the NE-SW trend on the pegmatites.

\section{References}

Brown, M., and G.S. Solar, 1998. Granite ascent and emplacement during contractional deformation in convergent orogens. J. Structural. Geol. 20, 1365-1393.

Collins, W.J. and E.W. Sawyer, 1996. Pervasive granitoid magma transfer through the lower and middle crust during non-coaxial compressional deformation. J. Metamorph. Geol. 14, 565-579.

Daas, M.A., 2009. Geochemical and geochronological studies on the Neoproterozoic granitoids between G. Dara and G. Gharib Area, North Eastern Desert, Egypt. M. Sc. Thesis, Faculty of Science, Menoufiya Univ., $173 \mathrm{p}$.

Delvaux, D. and B. Sperner, 2003. New aspects of tectonic stress inversion with reference to the Tensor program. Geol. Soc., London, Sp. Publ., 212, 75-100.

Grocott, J., M. Brown, R.D. Dallmeyer, G.K. Taylor and P.J.Treloar, 1994. Mechanisms of continental growth in extensional arcs: an example from the Andean plate-boundary zone. Geology, 22, 391394.

Hamimi, Z., M.A. Abd El-Wahed, H.A. Gahlan and S.Z. Kamh, 2019. Tectonics of the Eastern Desert of Egypt: key to understanding the Neoproterozoic evolution of the Arabian- Nubian Shield (East African Orogen). In: A. Bendaoud et al. (eds.), The Geology of the Arab World-An Overview. Springer Nature, Switzerland, P. 1-81.

Hutton, D.H.W., 1988. Granite emplacement mechanisms and tectonic controls: inferences from deformation studies. Transactions Royal Society Edinburgh, Earth Sciences 79, 245-255. 
Perinçek, D., S. Saner, and K.G. Al-Hinai, 2006. Rejuvenation of the Pre-Cambrian Najd Fault System and its Importance in the Oil Province of Saudi Arabia. Mineral Res. Exp., Bull., 132, 73-82.

Shalaby, M.H., 1985. Geology and radioactivity of Wadi Dara Area, north Eastern Desert, A.R.E. Ph.D. Thesis, Faculty of Science, Alex. Univ., 165p.

Sawyer, E.W., 1994. Melt segregation in the continental crust. Geology 22, 1019-1022.

Searle, M.P., R.R. Parrish, K. Hodges, A.J. Hurford, M.W. Ayres and M.J. Whitehouse, 1997. Shisha Pangma leucogranite, South Tibetan Himalaya: field relations, geochemistry, age, origin, and emplacement. J. Geol., 105, 295-318.

Solar, G.S., R.A. Pressley, M. Brown and R.D. Tucker, 1998. Granite ascent in convergent orogenic belts: testing a model. Geology, 26, $711-714$.

Stern, R. J., 1985. The Najd Fault System, Saudi Arabia and Egypt: a Late Precambrian rift-related transform system, Tectonics 4,497-511.

Sylvester, P. J., 1998. Post-collisional strongly peraluminous granites. Lithos 45, 29-44. 